\title{
GAGASAN REAKTUALISASI TEORI PIDANA ISLAM DAN RELEVANSINYA BAGI PEMBANGUNAN HUKUM DI INDONESIA
}

\author{
Junaidi Abdillah \\ Dosen Fakultas Tarbiyah dan Keguruan \\ UIN Raden Intan Lampung \\ email: junaidiabdillah02@g.mail.com
}

Diterima: 2 Desember 2016. Disetujui: 14 April 2017

Dipublikasikan: Mei 2017

\begin{abstract}
This paper describes the reform efforts of Islamic Criminal Law theory which initiated by Moslems theorists. Throughout this renewal, the author sees the potential to be the development of the development of Islamic Criminal Law in Indonesia. As far as we know that the transformation of Islamic Criminal Law (figh jinayab) into the National Law as still results in theories and epistemological debate in transformation effort. This paper is elaborate research with a juridical-normative approach. The analysis methods used is the general methodical elements such as interpretation and deductiveinductive also personal reflection. This paper concludes: through out the renewal of the theory in the figh, jinayah can be developed the theory of contemporary punishment by reactualization Islamic penalization theory. Then Islamic Criminal Law will be more down to be applied in Indonesia
\end{abstract}

Keywords: Reaktualisasi, Fiqh Jinayah, Teori Pemidanaan dan Transformasi 


\section{A. Pendahuluan}

Pembangunan dalam konteks transformasi hukum Islam pada wilayah jinayah (pidana) di Indonesia dinilai tidak semudah dalam pada bidang perdata: abwal al-syakhsyiyyah, mu'amalah dan lain-lainnya. ${ }^{1}$ Padahal kebijakan hukum pemerintah telah menjadikan figh jinayah sebagai bahan baku pembentukan hukum pidana Indonesia yang dapat menggantikan Kitab Undang-undang Hukum Pidana (KUHP) yang dipandang sudah tidak relevan lagi dengan semangat zaman. ${ }^{2}$ Namun sampai saat ini, cita-cita transformasi dan legislasi fiqh jinayah sebagai pengganti KUHP di Indonesia masih sebatas cita-cita.

Pada titik inilah konteks inilah muncul problem serius yang dirumuskan dalam pertanyaan mendasar, bagaimana kita memahami dan melaksanakan figh jinayah dalam konteks keIndonesia-an? Atau dengan bahasa yang lebih lugas, bagaimana kita memasukkan fiqh jinayah sebagai bagian dari sistem tata hukum nasional bangsa Indonesia?

Untuk menjawab persoalan di atas tidak terlalu mudah karena banyak asumsi yang berkembang di masyarakat baik dari kalangan umat Islam sendiri maupun non-muslim. Pertama, dari kalangan umat Islam --terutama dari golongan kulturalistik-- memandang formalisasi hukum Islam (termasuk fiqh jinayah) akan membuka peluang intervensi

${ }^{1}$ Ibnu Burdah (ed.), Membumikan Hukum Langit: Nasionalisasi Hukum Islam dan Islamisasi Hukum Nasional Pasca Reformasi, (Yogyakarta: Tiara Wacana, 2008), h. 114.

${ }^{2}$ Lihat dalam Undang-undang nomor 10/2004 tentang pembentukan peraturan perundang-undangan. Dalam pasal 53 dinyatakan: "masyarakat berhak memberikan masukkan secara lisan atau tertulis dalam rangka penyiapan dan pembahasan rancangan undang-undang dan rancangan peraturan daerah". Hal ini dapat dipahami bahwa sejatinya hukum Islam telah diakui sebagai bahan baku bagi pembangunan hukum nasional. Dan, jika masyarakat menghendaki, hukum pidana Islam dapat diajukan menjadi rancangan Undang-undang dan Peraturan Daerah (perda) di Indonesia. 
negara terhadap agama. Negara dalam hal ini tidak diperkenankan campur tangan, apalagi melakukan pembatasan dan mendorong wilayah "hukum Islam yang resmi" dan "hukum Islam yang tidak resmi". Terlebih formalisasi hukum Islam yang dikhawatirkan akan dijadikan alat penguasa untuk menindas umat Islam sendiri. ${ }^{3}$

Pada sisi lain, ada sebagian kelompok umat Islam yang "ngotot" bahwa hukum Islam --termasuk fiqh jinayah-- harus menjadi bagian dari hukum nasional baik simbol maupun substansinya, termasuk sepenuhnya mengadopsi sepenuhnya bentuk-bentuk hukuman yang secara literal tercantum dalam Alqur'an. ${ }^{4}$ Sebab dengan formalisasi tersebut, maka hukum Islam dapat berjalan efektif, bersifat memaksa dan mempunyai kekuatan hukum.

Kedua, kekhawatiran dari umat non-muslim jika figh jinayah diadopsi menjadi hukum nasional. Ketakutan mereka bisa dimaklumi, sebab jika bentuk-bentuk hukum dalam figh jinayah diadaptasi dan diterapkan sepenuhnya, maka akan banyak dijumpai di jalanan orang yang dipotong tangannya, atau orang yang ditanam kemudian dilempari batu oleh massa hingga mati karena terbukti berzina, dan bentuk-bentuk lainnya.

Berangkat dari uraian di atas, tampak nyata bahwa untuk melakukan transformasi fiqh jinayah sebagai hukum nasional di Indonesia bukanlah problem yang mudah. Dengan demikian, hal yang paling mendesak adalah melakukan pembaruan teori-teori pemidanaan dalam pidana Islam. Melalui jalan dan metode ini, maka akan ditemukan "jalan keluar" bagi kebuntuan dan melangitnya hukum pidana Islam di Indonesia. Melalui pembaruan dan reaktualisasi ini

${ }^{3}$ Selengkapnya baca dalam buku karya Abdul Ghofur, Demokratisasi dan Prospek Hukum Islam di Indonesia: Studi atas Pemikiran Gus Dur (Yogyakarta: Pustaka Pelajar, 2002).

${ }^{4}$ Saiful Mujani, Muslim Demokrat: Islam, Budaya Demokrasi dan Partisipasi Politik di Indonesia Pasca Orde Baru, (Jakarta: Gramedia, 2007) h. 26-27. 
pula, hukum pidana islam diharapkan bisa membumi dan aplikatif di Indonesia.

\section{B. Pembahasan}

\section{Beberapa Teori Pembaruan Hukum Pidana Islam}

Pada era kontemporer ini, kecenderungan ke arah reaktualisasi (pembaharuan) hukum pidana Islam senantiasa bergelora. Kecenderungan semacam ini dirasakan sangat relevan terutama dalam rangka penghadapan antara Islam dan tatanan dunia baru sekarang ini. Untuk itulah gagasan para pemikir Islam kontemporer semisal Fazlur Rahman, Muhammad Taha, al-Na'im, Muhammad Syahrur dan Ibrahim Hossen perlu mendapat perhatian tersendiri. Berikut ini akan penulis elaborasi teori-teori baru dalam upaya pembaruan hukum pidana Islam.

\section{a. Teori “Double Movement” Fazlur Rahman}

Fazlur Rahman --seorang peneliti senior dari Pakistan- dalam memahami ayat-ayat pidana budūd lebih cenderung menggunakan metode kritik sejarah dalam memahami ayatayat hudūd dalam Alqur'an. Metode ini terdiri dari tiga langkah utama: pertama, pendekatan historis untuk menemukan makna teks-teks Alqur'an dalam bentangan dakwah Nabi. Kedua, membedakan antara ketetapan legal dan sasaran serta tujuan Alqur'an. Ketiga, memahami dan menetapkan sasaran Alqur'an dengan memperhatikan secara penuh latar belakang sosiologisnya. ${ }^{5}$

Rahman mengakui adanya kesulitan dan potensi perbedaan dalam pendekatan sosiologis ini. Meskipun

${ }^{5}$ Fazlur Rahman, "Islamic Modernism: Its Scope, Method and Alternatives" dalam International Journals of Middle East Studies, Vol. I, tahnun 1970, h. 329-330. Sebagaimana dikutip oleh Taufik Adnan Amal, Islam dan Tantangan Modernitas, Studi Atas Pemikiran Hukum Fazlur Rabman (Bandung: Mizan, 1994) h. 189-220. 
demikian, pendekatan ini dapat mengantarkan pada solusi yang memuaskan. Sebagai contoh, kasus hukum potong tangan dalam kasus pencurian yang ditetapkan Alqur'an. Berkaitan dengan hal ini, Rahman mengkritik para fuqaha' klasik yang mencoba mencari jalan keluar dengan membuat definisi pencurian yang sangat sempit dan dengan menerapkan prinsip "keuntungan dari kesangsian" dengan kemurahan hati yang luar biasa pada semua kasus dari apa yang disebut hudüd. Pada sisi lain, Rahman juga mengkritik para ahli hukum modern yang menafsirkan "potong tangan" dengan tafsir metaforis bahwa maksud tangan dalam ayat tersebut bukanlah tangan sesungguhnya, melainkan dalam arti majari. ${ }^{6}$

Terkait ayat-ayat pidana $\underline{b u d \bar{d}}$ Rahman menekankan pendekatan sosiologis sistematis. Dalam kasus hukum potong tangan misalnya, kacamata sejarah telah menampilkan bahwa penerapan pidana ini telah berlaku di kalangan beberapa suku sebelum Muhammad yang kemudian diadopsi oleh Alqur'an. Pada konsep pencurian, menurut Rahman, ada dua unsur utama yang harus dilihat. Yaitu kesalahan mengambil barang secara ekonomi dan pelanggaran hak milik pribadi. Pada setting suku-suku tersebut, hak milik betul-betul sarat dengan rasa kemulia-an personal dan pencurian tidak dianggap sebagai kejahatan ekonomi. Namun pada konteks masyarakat Arab pra-Islam, pencurian merupakan kejahatan mela-wan nilai-nilai kemuliaan personal dan kesucian yang tidak dapat diganggu gugat. Dalam ini berbeda konteks dengan masyarakat modern yang telah mengalami pergeseran nilainilai terkait pencurian. Menurut Izzu al-Din Abd al-Salam teoritisi Syafi'iyyah mengatakan bahwa banyak orang memiliki tendensi untuk memaaf-kan pencuri dengan tidak simpatik padanya dan pencurian lebih pada kesalahan menghilangkan 
dari pemilik oleh pencuri dari hak sebelumnya untuk mengguna-kan aset atau fasilitas ekonomi tertentu. Pergeseran nilai-nilai inilah yang menurut Rahman mengharuskan perubahan bentuk pidana potong tangan dalam kasus tindak pidana pencurian. ${ }^{7}$

\section{b. Teori Dekonstruksi Syari'ah al-Na'im}

Nama lengkap An-Na'im adalah Abdullahi Ahmed An-Na'im lahir 6 April 1946 di daerah Mawaqier $200 \mathrm{~km}$ dari utara Khartoum Sudan. Setamat dari pendidikan SLTA, ia melanjutkan studi di fakultas Hukum Universitas Khartoum (1965-70) dengan gelar LL.B dan pada 1973 meraih gelar LL.M dan gelar MA diraihnya pada tahun 1976. Dan puncaknya, pada 1976 Abdullahi mampu meraih gelar Ph.D dalam bidang ilmu hukum dari Universitas Edinburg, Skotlandia. ${ }^{8}$

Teori yang diusungnya dikenal dengan konsep "dekonstruksi syariab". Menurutnya, syari'ah bukanlah keseluruhan Islam itu sendiri, melainkan hanya interpretasi terhadap teks dasarnya sebagaimana dipahami dalam konteks historis tertentu. Penafsiran dan praktik keberagamaan, tidak dapat dilepaskan dari kondisi sosiologis, ekonomi dan politik masyarakat tertentu, tentu saja ada variasi dan kekhasan lokal, demikian hanlnya sistem hukum agama seperti syariah. dengan demikian, syariah yang telah disusun oleh para ahli hukum perintis dapat direkonstruksi pada aspek-aspek tertentu, dengan catatan tetap berdasarkan pada sumber dasar Islam yang sama dan sepenuhnya sesuai dengan pesan moral dan agama. Karenanya, An-Na'im menggugat sakralisasi hasil pemahaman syariah historis, terlebih ia menilai syariah, sudah

${ }^{7}$ Fazlur Rahman, "The Concept of Hadd in Islamic Law" dalam Islamic Studies Journal, Vol. IV, No. 3 September 1965, h. 237.

${ }^{8}$ Abdullahi Ahmed An-Na'im, "Mahmud Muhammad Taha and Crisis in Islamic Law Reform: Implications for Interreligious Relations", Journal of Ecumential Studies 25: 1 (1988), h. 177. 
tidak lagi memadai dan tidak adil, padahal syariah dipandang umat Islam merupakan bagian dari keimanan. ${ }^{9}$

Dalam melakukan pembaruan teori-teori hukum publik Islam, An-Na'im berangkat dan menggunakan teori gurunya Mahmoud Mohammed Taha yang dikenal dengan teori naskh atau teori "naskh terbalik". Teori ini sejatinya merupakan bentuk upaya rekonstruksi dari metode nasak $h^{10}$ yang sudah mapan dalam kajian ushül al-fiqh. Pendekatan rekonstruktif ini, An-Na'im tempuh dalam rangka menyesuaikan nash-nash Alqur'an dan al-Sunnah dengan kondisi modern. Hal ini dilakukan guna memenuhi tuntutan penerapan Alqur'an dan al-Sunnah. Karenanya, perlu interpretasi yang memadai agar semangat yang dikandungnya dapat ditangkap. ${ }^{11}$

Lebih lanjut, an-Na'im berpendapat bahwa hukum publik (pidana) Islam terutama aspek hudûd, qisās dan yang sejenisnya, dinilai dapat dijadikan landasan dan konsisten

${ }^{9}$ Abdullahi Ahmed An-Na'im, Toward an Islamic Reformation: Civil Liberties, Human Rights and International Law (New York: Syracuse University Press, 1996) h. xiv dan Lihat juga Abdullahi Ahmed An-Na'im, Islam dan Negara Sekuler; Menegosiasikan Masa Depan Syari'ah, terj. Sri Murniati (Bandung: Mizan, 1997), h. 27.

${ }^{10}$ Diketahui bahwa dalam Alqur'an ada ayat yang hukumnya muncul belakangan, maksudnya ayat turunnya terlebih dahulu, kemudian hukum-hukum syariah dan figh yang terkandung di dalamnya baru bisa diterapkan belakangan. Sehingga melahirkan metode naskh. Termasuk kesepakatan bahwa banyak ayatayat makkiyah yang dihapus oleh ayat-ayat madaniyyah. Terkait kategorisasi di atas, ada tiga pandangan ulama ushul fiqh ketika mendiskusikan ayat-ayat makkiyyah dan madaniyyah dengan pandangan sebagai berikut: pertama, sebagian ulama berpendapat bahwa ayat-ayat makkiyah diturunkan sebelum Nabi Hijrah, sedang ayat-ayat madaniyyah diturunkan sesudah Hijrah. Kedua, Sebagian ulama berpandangan bahwa ayat-ayat makkiyah adalah ayat-ayat yang diturunkan di kota Makkah, meski Nabi sudah hijrah. Ketiga, sebagian lagi ulama menentukan dari sisi isi dan tujuan ayat-ayat tersebut. Biasanya ayat-ayat makkiyyah diawali dengan redaksi "ya ayyuha al-nas" sedangkan ayat-ayat madaniyyah diawali dengan ya ayyubal ladrina amanu.." Lihat dalam Mababist fi Ulum al-Qur'an, karya Manna' al-Qathhan, (t.tp, Mansyurat al-“Ashr al-Hadits, t.th.), h. 56.

11 A. Luthfi Assyaukanie, "Tipologi dan wacana Pemikiran Arab Kontemporer" dalam Jurnal Pemikiran Islam Paramadina”, vol. 1, No. 1, 1998. 
dengan konteks historisnya. Namun, menurutnya, tidak dapat dijadikan alasan dan (tidak secara) konsisten bersesuaian dengan konteks kekinian. Berbagai aspek pada hukum publik syariah --dalam konteks politik-- tidak lagi akurat atau tidak lagi fungsional. ${ }^{12}$ Baginya yang sempurna adalah yang selalu melakukan perubahan dan perkembangan. Kesempurnaan manusia ia ilustrasikan dengan kondisi Tuhan yang selalu memperbarui diri-Nya. Sebagaimana dalam surat ar-Rahman ayat 29 .

Berangkat dari argumentasi di atas, an-Na'im berpendapat bahwa hukum publik, termasuk pidana, yang tepat untuk dilaksanakan adalah hukum Islam yang tepat untuk diimplementasikan saat ini adalah hukum Islam yang berdasarkan realitas konkret, bukan Tuhan. Sehingga dapat menyelesaikan masalah dan tepat sasaran. Standar kesahihan dan ketepatannya adalah pembelaan nilai-nilai kemanusiaan dengan didukung oleh dua argumen: argumen yang bersifat moral dan argumen yang bersifat empiris. Dalam teori dekonstruksinya, an-Na'im menekankan prinsip resiprositas dan mengikuti praktik-praktik kehidupan bangsa-bangsa modern. Umat Islam boleh menerapkan hukum Islam dengan catatan tidak melanggar legitimasi hak perorangan dan kolektif pihak lain. Karena itu, yang bisa dilakukan adalah membangun hukum pidana Islam alternatif. Dalam kerangka inilah maka yang dibutuhkan adalah melakukan reinterpretasi teks-teks hukum publik (pidana) syari’ah.

\section{c. Teori Batas (Nazhariyyah al- $\underline{H} u d u \bar{u}$ ) Muhammad Syahrur}

Teori "batas" atau lazim dikenal dengan nazhariyyat al-

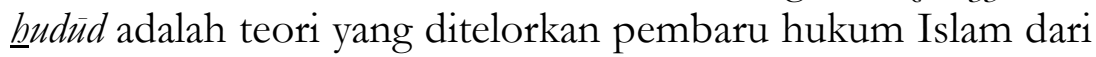
Syria bernama Muhammad Syahrur ${ }^{13}$. Dengan latar belakang

${ }^{12}$ Abdullahi Ahmed am-Na'im, op. cit., h. 34.

${ }^{13}$ Nama lengkap Syahrur adalah Muhammad Syahrur al Dayyub. Lahir di Damaskus 11 April 1938. Ia menempuh pendidikan dasar dan 
sarjana fisika, ia mencoba membangun teori pembaruan hukum pidana Islam dari kacamata ilmu alam, terutama ilmu matematika dan fisika. Dalam Kitabnya yang berjudul: al-Kitab wa al-Qur'an; Qira'ah Mu'asharah Syahrur mengemukakan bawa dalam syari'at Islam terdapat ketentuan batas minimal (al-badd al-adna) dan batas maksimal (al-badd al-a'la). Perbuatan hukum yang kurang dari batas minimal dan melebihi batas maksimal dipandang tidak sah. Ketika batas-batas tersebut dilanggar, maka pidana dan pemidanaan harus dijatuhkan menurut proporsi pelanggaran yang dilakukan. ${ }^{14}$

Bagi Syahrur, wilayah ijtihad manusia dalam hukum Islam berada di antara batas-batas tersebut. Dengan cara ini, maka hukum Islam dapat dikembangkan sesuai realitas dan perubahan kondisi dalam masyarakat. Dalam hal ini, Syahrur mencontohkan penentuan jenis hukuman atas tindak pidana pencurian dan pembunuhan. Menurutnya, hukuman yang dapat dilakukan bisa hukuman minimal dengan cara tidak menghukum atau hukuman maksimal.

Setelah mengkaji ayat-ayat hukum, Syahrur kemudian menyimpulkan ada enam bentuk dalam teori batas-nya. Pertama, ketentuan hukum yang hanya memiliki batas bawah. Misal dalam perkawinan khususnya wanita-wanita yang haram

menengah di lembaga pendidikan Abdurrahman al Kawakibi, Damaskus. Pada tahun 1957, Syharur menyelesaikan pendidikan menengahnya dan mendapatkan beasiswa dari pemerintah Suriah untuk melanjutkan studi dalam bidang teknik sipil di Moskow, Rusia. Ia memperoleh gelar Diploma pada tahun 1964 dan melanjutkan studi ke Universitas Nasional Irlandia dengan beasiswa dari Universitas Damaskus dalam bidang spesialis mekanika pertahanan dan pondasi. Di sana beliau memperoleh gelar Master of Science pada tahun 1969 dan gelar Philosophy Doctor pada tahun 1972 M. Hingga saat ini beliau masih menjadi dosen di fakultas Teknik Sipil Universitas Damaskus dalam bidang Mekanika tanah dan Geologi. Selain itu beliau juga medirikan biro konsultasi teknik Dar alIsytisyarat al-Handasiyyah di Damaskus. Beliau juga tertarik pada ilmu filsafat dan keIslaman, seperti: Filsafat Humanisme, Filsafat Bahasa, dan Semantika Bahasa Arab. Lihat Ahmad Zaki Mubarok, Pendekatan Strukturalisme Linguistik dalam tafsir Alquran (Yogyakarta: Elsaq Press, 2007) h.137-139.

${ }^{14}$ Muhammad Syahrur, al-Kitab wa Alqur'an; Qira'ah Mu'asharah (Damaskus: al-Ahali, 1990) h. 580. 
dinikahi. Jumlah wanita yang haram dinikahi merupakan batas minimal yang tidak boleh menguranginya, ijtihad hanya diperbolehkan menambah jumlah wanita, misalnya anak paman (bibi) juga bisa masuk dalam wanita yang haram dinikahi. Kedua, ketentuan hukuman yang hanya mempunyai batas maksimal saja. Ini berlaku dalam tindakan pencurian dan pembunuhan. Dalam pencurian, hukuman maksimalnya dalah potong tangan, tidak lebih dari itu. Maka boleh menghukum lebih rendah dari potong tangan. Ketiga, ketentuan hukum yang mempunyai batas minimal dan batas maksimal sekaligus. Hukum waris 1:2 misalnya, dalam hal ini bisa berubah sesuai kondisi laki-laki dan wanitanya. Keempat, ketentuan hukum yang mana antara batas minimal dan batas maksimal berada dalam satu titik. Dalam hal ini hukuman tidak boleh kurang dan tidak boleh melebihi. Misalnya, dalam hukuman zina dengan dera 100 kali. Kelima, ketentuan yang mempunyai batas maksimal dan minimal, namun kedua batas tersebut tidak boleh tersentuh, sebab dengan menyentuhnya sama halnya dengan melanggar larangan Tuhan. Seperti pergaulan antara laki-laki dan perempuan yang dimulai dari tidak menyentuh sama sekali (batas minimal) sampai pada hubungan yang mendekati zina, maka keduanya belum terjatuh pada pelanggaran Allah, karena batas maksimalnya dalah berzina. Keenam, ketentuan hukum yang mempunyai batas maksimal dan minimal, dalam hal ini, batas atas berkonotasi positif $(+)$ dan tidak boleh dilampaui, sementara batas minimal berkonotasi negatif (-) yang berarti boleh dilampaui. Dalam hal ini batas maksimal ini dicontohkan dengan riba, sedangkan batas minimal adalah zakat dimana zakat dapat dilampaui dengam amal-amal semisal sedekah, infak dan lain-lainya. ${ }^{15}$

${ }^{15}$ Wael B. Hallaq, A History of Islamic Legal Theories (Sejarah Teori Hukum Islam; Pengantar Untuk Ushul al-Figh Madz̧ab Sunni) terj. E. Kusnadiningrat dan Abdul Haris, (Jakarta: Rajawali Pers, 2000), h. 366-369. 
Teori batas (ㅁudūd) tawaran Muhammad Syahrur merupakan gagasan yang kontroversial di Timur Tengah di tengah arus deras keterpakuan teks. Teori ini ini memandang bahwa syariat Allah sejatinya hanyalah syari'at yang berupa

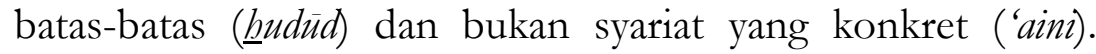
Karena itu, tugas manusia (mujtahid) hanya menemukan budūd Allah dalam ayat-ayat umm al-Kitāb, kemudian setelah budūd Allah ditemukan, ia harus membentuk hukum yang sesuai dengan tuntutan realitas, namun tidak diperbolehkan menyalahi atau melampaui budūd (batasan) Allah tersebut. Teori budüd Syahrur merupakan perangkat dan alat (tool and instrument) dalam berijtihad yang bertujuan untuk mewujudkan hukum Islam modern yang fleksibel, dinamis dan relevan dengan kebutuhan dan tuntutan realitas.

\section{d. Teori "zawäjir"Ibrahim Hossen}

Teori zawäjir adalah teori yang dicetuskan Ibrahim Hossen $^{16}$ seorang pemikir Hukum Islam dari Indonesia. Terkait pembaruan hukum pidana Islam, ia kemudian

Bandingkan dengan Imam Syaukani, Rekonstruksi Epistemologi Hukum Islam Indonesia (Jakarta: Raja Grafindo Persada, 2006), h. 143-146.

${ }^{16}$ Ibrahim Hosen lahir di Lampung 1 Januari 1917 dan wafat 7 November 2001. Secara formal, Ibrahim Hosen memulai pendidikannya pada Madrasah al-Sagaf, tingkat Ibtidaiyah di Singapura, kemudian melanjutkan pendidikan di Mu'awanatul Khaer Arabische School (MAS) di Tanjung Karang Lampung yang didirikan orang tuanya. Pada tahun 1932 dia melanjutkan sekolahnya di Teluk Betung. Pada 1934, beliau belajar di beberapa pesantren di Jawa dan pada tahun 1955, ia Studi ke Universitas al-Azhar Kairo. Selama belajar di Mesir inilah, ia dapat meraih Suahadah Aliyah atau sarjana lengkap dalam bidang Syari'ah (LML). Ia ditahbiskan sebagai Mujtahid dari Ciputat oleh Majalah Tempo pada 1 Desember 1990. Sembilan belas tahun kemudian, atau tepatnya pada 6 Mei 2009, Majalah Gatra menahbiskannya sebagai salah satu ilmuwan pelopor Indonesia: Beliau dikenal sebagi Pakar ushul fikih (filsafat hukum Islam) dan fikih perbandingan dan memimpin Komisi Fatwa Majelis Ulama Indonesia (MUI) dua dasawarsa (1981-2000). Terkait biografi Ibrahim Hosen lihat Panitia Penyusunan Biografi Prof. KH. Ibrahim Hosen, Prof. KH. Ibrahim Hosen dan Pembaharuan Hukum Islam di Indonesia (Jakarta; CV. Tiga Sembilan, 1990), h. 1. 
menawarkan pendekatan zawäjir. ${ }^{17}$ Yakni Dalam pendekatan ini hukuman dalam pidana Islam yang dijatuhkan terhadap pelaku tindak pidana tidak harus persis atau sama bentuk hukumannya dengan apa yang secara tekstual termaktub dalam Alqur'an dan al-Hadits. Pelaku boleh dihukum dengan bentuk hukuman apa saja. Dengan catatan hukuman tersebut mampu mencapai tujuan hukum yaitu membuat jera pelaku dan menimbulkan rasa takut bagi orang lain untuk melakukan tindakan pidana. ${ }^{18}$

Pendekatan zawäjir memang mirip dengan teori batas ( $\underline{\text { hudūd) }}$ yang ditawarkan Syahrur. Perbedaannya, teori $\underline{\text { hudūd }}$ mempunyai kelemahan pada sisi penetapan hukum potong tangan bagi pencuri sebagai hukuman maksimal ( badd al'ala). Dengan model yang demikian maka teori batas tidak bisa diterapkan secara dalam segala bentuk ruang dan waktu. Sebab, jika pidana potong tangan dipandang sebagai pidana yang maksimal, maka tujuan dari pemberian pidana agar membuat jera bagi pelaku dan orang lain, dimungkinkan tidak tercapai. Dalam kasus seorang pencuri kambuhan misalnya, tentunya pidana yang tepat tentunya tidak cukup dengan dipotong tangannya. Pada titik inilah, pendekatan zawäjï yang sifatnya lebih umum akan lebih sesuai diterapkan di

${ }^{17}$ Terkait dengan pendekatan legislasi al-fiqh al-jinầ $\hat{\imath}$ paling tidak ada dua model pendekatan yang dilakukan oleh para ahli hukum. Yaitu pendekatan jawâbir (paksaan) dan pendekatan zawäjir (pencegahan). Pendekatan jawâbir adalah menghendaki pelaksanaan hukuman pidana persis seperti hukuman yang secara tekstual literal disebutkan di dalam nash Alqur'an dan hadits. Semisal potong tangan bagi pencuri, rajam dan jilid bagi pezina, cambuk bagi peminum khamr dan sebagainya. Bentuk hukuman semacam ini dilaksanakan dengan tujuan untuk menebus dosa dan kesalahan yang telah dilakukan. Pendekatan jawâbir ini yang nampaknya dijadikan model penerapan perda syariat di Provinsi Nangroe Aceh Darussalam yang dalam praktiknya banyak menuai badai kritikan dari para pemikir hukum Islam khususnya di Indonesia. Lihat Nurrohman dan Marzuki Wahid, Formaslisasi Syari'at Islam dan Fundamentalisme, Kasus Nanggroe Aceh Darussalam dalam Jurnal Istiqro' Volume 01, Nomor 1, 2002, h. 45-74.

${ }^{18 J u h a y a}$ S. Praja, Teori Hukum dan Aplikasinya, (Bandung: Pustaka Setia, 2011), h. 86-87. Lihat juga dalam karya Ibrahim Hosen, Pembaruan Hukum Islam di Indonesia, (Jakarta: Putra Harapan, 1990) h. 126-128. 
Indonesia. Sebab dalam pendekatan ini, hukuman bisa maksimal dan bisa minimal tergantung pada kebutuhan. ${ }^{19}$

Dalam rumusan ijtihadnya, khususnya pada bidang hukum pidana Islam, Ibrahim Hosen menggunakan pendekatan ta'aqqui dari pada pendekatan ta'abbudi (hukum Islam diterima apa adanya tanpa disertai komentar (rasionalisasi). Pendekatan ta'aqquli lebih menekankan rasionalisasi ajaran dalam hukum Islam agar mudah dipahami dan dapat dilaksanakan secara simultan dalam teori dan praktiknya secara bersamaan. Namun demikian, ia juga mengakui terdapat ajaran hukum Islam yang bersifat $t a^{\prime} a b b u d i$ semata. Dan, ia tetap menekankan agar ajaran yang selama ini dipandang ta'abbudì agar diteliti ulang lebih lanjut, sehingga terbuka kesempatan untuk menjadikannya sebagai sesuatu yang ta'aqquli dengan tetap berlandaskan pada maquashid alsyar' ah, pemahaman 'illat dan hikmah tasyri'. ${ }^{-20}$

Pendekatan ta'aqqui tercermin dalam pemikiran Ibrahim Hosen yang menekankan aspek zawäjir dalam penerapan hukum pidana Islam, terutama aspek budūd. Yaitu hukuman dilaksanakan dengan tujuan agar si-pelaku kejahatan merasa jera dan tidak akan mengulangi lahi tindak pidana lagi. Atas dasar ini, pezina tidak harus dihukum sesuai apa yang tertera dalam Alqur'an dan hadits. Demikian halnya, pencuri

${ }^{19}$ Teori zawajir ini ternyata sejalan dengan teori behavioral prevention. Artinya, hukuman pidana harus dilihat sebagai cara agar yang bersangkutan tidak lagi berada dalam kapasitas untuk melakukan tindak pidana (incapacitation theory) dan pemidanaan dilakukan untuk memudahkan dilakukannya pembinaan, yang bertujuan untuk merahibilitasi si terpidana sehingga ia dapat merubah kepribadiannya menjadi orang baik yang taat pada aturan (rehabilitation theory). Teori ini merupakan pengembangan dari deterrence theory yang beraharp efek pencegahan dapat timbul sebelum pidana dilakukan (before the fact inhabition), misalnya melalui ancaman, contoh keteladanan dan sebagainya; dan intimidation theory yang memandang bahwa pemidanaan itu merupakan sarana untuk mengintimidasi mental si terpidana. Lihat dalam karya Bahtiar Effendy, Bahtiar, Islam dan Negara: Transformasi Pemikiran dan Praktik Politik Islam di Indonesia, (Jakarta: Paramadina, 1998).

${ }^{20}$ Juhaya S. Praja., op. cit., h. 95. 
bisa saja dihukum dengan hukuman selain potong tangan, selagi hukuman tersebut mampu membuat jera pelaku. Lebih lanjut, ia menyatakan bahwa sanksi-sanksi dalam hukum pidana Islam adalah lebih berfungsi sebagai zawäjir (penjeraan) bukan penghapus dosa (jawäbir) hal ini bisa dilihat dari adanya konsep pemaafan, baik dalam pertaubatan maupun pemaafan dari korban, dalam hukum pidana Islam tersebut. Dalam pidana potong tangan misalnya, hukum potong tangan hanya sebatas wasilah (instrumen) bukan tujuan utama (ghayah). ${ }^{21}$

Adapun metode ijtihad yang dipakai oleh Ibrahim Hosen adalah: (a) Pemahaman kontekstual Alqur'an dan Hadits (b) hanya menggunakan ijma' sahabat yang sharih (jelas) (c) lebih menggunakan kaidah fiqh irtikāb akhaff aldlararain dan kaidah bukm al-häkim iląàmun wa yarfa'u al-khiläf dan (c) mem-fiqbkan hukum yang qath'?. Khusus metode terakhir, Ibrahim memandang bahwa tidak semua hukum qath'i dalam ranah aplikasinya berlaku dalam segala ruang dan waktu. Terkadang ia hanya berlaku dalam kondisi ruang, waktu dan kondisi tertentu saja.

\section{Aspek Epistemologis}

Gerakan pembaruan hukum Islam --termasuk hukum publik Islam-- tidak dapat dilepaskan dari aspek dan pengaruh pluralitas sosial-budaya, politik dalam suatu masyarakat dan negara. Para ulamā'/fuqāhā' seringkali menafsirkan teks-teks Alqur'an dan Sunnah dalam konteks sosial-budaya dan politik. ${ }^{22}$ Fakta sejarah menunjukkan pada masa Islam yang begitu awal, telah lahir berbagai madzhab fiqh, ada madzhab Hijaz, madzhab Irak dan Syiria. ${ }^{23}$ Kendati demikian, rumusan

${ }^{21}$ Ibid., h. 96.

${ }^{22}$ A. Qodri A. Azizy, Eklektisisme Hukum Nasional; Kompetisi Antara Hukum Islam dan Hukum Umum, (Yogyakarta: Gama Media, 2002), h. 32-33

${ }^{23}$ Abd al-Wahhab Ibrahim Abi Sulaiman, al-Fikru al-Ushuli; Dirasah Tabliliyyah Naqdiyyah, (Jeddah: Dar al-Syuruq, 1983), Cet. ke-1, h. 44-46 
teori hukum Islam baru ditemukan pada abad ke-2 $\mathrm{H}$. Tercetus oleh seorang bernama al-Syafi'i melalui karyanya alRisālah. ${ }^{24}$ Selanjutnya, gagasan pembaruan hukum Islam diteruskan oleh al-Ghazali (w.505/1111) dengan membangun teori mashlabah, dan kemudian dilanjutkan oleh al-Syāthibî (790/1138). Dan, pada awal fase modern muncul Muhammad Abduh (w.1905) dengan rekonstruksi rasionalisme klasik. ${ }^{25}$

Secara umum, pola pembaruan hukum Islam, telah terbagi menjadi dua kelompok: pertama, kelompok ahli hukum Islam (fuqāha//mujtabid) yang dikategorikan dengan aliran "tekstual-teosentris". Kelompok ini selalu menjadikan teksteks Alquran dan Sunnah sebagai pijakan utama dalam justifikasi aktivitas mereka. Artinya, teks-teks yang jelas dan rinci dalam bidang hukum Islam yang terdapat dalam Alquran dan sunnah dan kitab-kitab karya ahli fiqh tradisional harus diterima apa adanya tanpa membutuhkan tafsir ulang. ${ }^{26}$ Kedua, kelompok ahli hukum yang diidentikkan dengan orang legal theorists. Yakni kelompok yang berpandangan bahwa agar hukum Islam selalu mampu menjawab tantangan zaman dan tak kehilangan elan vitalnya, maka pintu ijtihad harus dibuka selebar-lebarnya. Mereka ini sering diidentikkan dengan

${ }^{24}$ Terkait siapa sejatinya penemu ilmu ushul al-figh masih menjadi perdebatan. Secara praktis praktik-praktik hukum berbasis pembaruan telah ada sebelum Asy-Syafi'i. Tidak mengherankan jika dari kalangan Ahnaf, mengklaim bahwa Abu Hanifah, Syaibani dan Abu Yusuf adalah tokoh-tokoh peletak ilmu ushul al-figh. Dapat dikatakan pada era mereka memang telah terbentuk metodologi hukum Islam, namun masih membaur dengan kajian-kajian lainnya, semisal fiqh dan sebagainya. Baru pada era al-Syafi'i, beliaulah yang menyusun ilmu Ushul al-Figh secara sistematis dan terpisah dari ilmu-ilmu lainnya. Detainya lihat karya Abd al-Wahhab Ibrahim Abi Sulaiman, op. cit. h. 5-6.

${ }^{25}$ Syamsul Anwar, "Pengembangan Metode Penelitian Hukum Islam" dalam Ainurrofiq (ed.), Mą̧hab Jogja”; Menggagas Paradigma Ushul Fiqh Kontemporer (Yogyakarta: Ar-Ruzz Press dan Fakultas Syariah IAIN Sunan Kalijaga, 2002) h. 148-149.

${ }^{26}$ Satria Effendi M, "Ijtihad Sepanjang Sejarah Hukum Islam: Memposisikan KH Ali Yafie" dalam Jamal D. Rahman (ed.) Wacana Baru Fiqh Sosial; 70 Tabun KH Ali Yafie (Bandung: Mizan, 1997), h. 154-155. 
kelompok yang mengedepankan peran akal dan memberikan porsi utama dalam menjawab realitas dan perubahan sosial. ${ }^{27}$

Pada perjalanan sejarah berikutnya, pembaruan hukum Islam selalu diwarnai perdebatan antara peran wahyu versus akal (teks versus konteks). Pertentangan antara Umar dan Sahabat lainnya terkait pembagian ghanimab28, terkait pemotongan tangan bagi pencuri, pertentangan antara Abu Hanifah dengan teori istihlsān-nya dengan penentangnya AsySyafi'i dengan teori qiyās-nya. Ini semua membuktikan kepada kita bahwa perdebatan wahyu versus akal, teks versus konteks, selalu menghiasi sejarah pembaruan hukum Islam, termasuk upaya-upaya reaktualisasi hukum pidana Islam (HPI).

Gelombang pembaruan hukum pidana Islam (HPI) sejatinya tidak bisa dilepaskan dari metodologi (baca: epistemologi) yang digunakan para pembaru tersebut. Harus diakui, antara epistemologi yang dipakai dengan produk ilmu yang dihasilkan mempunyai keterkaitan yang erat dan keduanya tidak dapat dipisahkan. Artinya, corak hukum dari seorang mujtahid sangat dipengaruhi metode (baca: episteme) yang dipakai oleh mujtahid itu sendiri. Keduanya, antara hasil hukum dengan epistemologi (metodologi) ibarat matahari dengan sinarnya yang tidak bisa dipisahkan.

Membedah tentang aspek epistemologi, maka tidak bisa lepas dari kajian filsafat. Dan, bagian filsafat yang dengan sengaja berusaha menjalankan refleksi atas pengetahuan manusia itu disebut "epistemologi" atau ajaran tentang pengetahuan. Karenanya, Amin Abdullah memandang bahwa episte-mologi merupakan salah satu cabang dari filsafat ilmu

${ }^{27}$ Ibid., h. 154.

${ }^{28}$ Ghanimah adalah harta yang diambil secara paksa dari golongan kafir barbi, baik dalam bentuk benda bergerak maupun benda yang tidak bergerak, baik diambil ketika pada saat peperangan masih berlangsung ataupun ketika memburu musuh yang melarikan diri. Sedangkan $f a^{\prime} i$ adalah harta yang diambil secara paksa tanpa melalui peperangan, sementara salab ialah harta atau senjata pribadi yang ada pada mayat tentara musuh yang terbunuh. 
yang memper-bincangkan "pengetahuan". Sebagaimana diketahui, bahwa perbincangan epistemologi tidak dapat meninggalkan persoalan-persoalan yang terkait dengan sumber ilmu pengetahuan dan beberapa teori tentang kebenaran. Sedangkan menurut Komaruddin Hidayat epistemologi dimaknai sebagai teori dan sistem tindakan dan cara pandang seseorang terhadap dunia sekitarnya. ${ }^{29}$ Sementara Harun Nasution mengatakan bahwa epistemologi merupakan ilmu yang membahas tentang dua ranah yaitu: apa itu pengetahuan, (hakikat) dan bagaimana cara memperoleh pengetahuan. ${ }^{30}$ Sedangkan Harold $\mathrm{H}$. Titus dkk. mengatakan bahwa kajian dalam epistemologi terdapat tiga persoalan yang selalu diperbincangkan. Pertama, apakah sumber-sumber pengetahuan itu? Dari manakah pengetahuan yang benar itu datang dan bagaimana mengetahui? Hal ini adalah persoalan tentang "asal" pengetahuan sendiri. Kedua, apakah watak pengetahuan itu? Apakah ada dunia yang benar-benar di luar akal-pikiran, dan kalau ada apakah kita mengetahuinya? Hal ini adalah persoalan tentang, apa yang kelihatan versus hakekatnya pengetahuan. Ketiga, apakah pengetahuan itu benar (valid)? Bagaimana dapat membedakan antara benar dan salah dalam pengetahuan? Hal ini adalah persoalan tentang kebenaran atau verifikasi pengetahuan yang telah diperoleh manusia. ${ }^{31}$

Berangkat dari paparan di atas, tampak para ahli filsafat ilmu menyatakan bahwa dalam kajian epistemologi, paling tidak ada tiga problema umum yang menjadi kajian di dalamnya. Yaitu persoalan hakikat pengetahuan, sumber dan metode dan validitas kebenaran untuk memperoleh 1996) h. 56-7.

${ }^{29}$ Komarudin Hidayat, Memahami Bahasa Agama, Jakarta: Paramadina,

${ }^{30}$ Harun Nasution, Filsafat Islam, (Jakarta: UI-Press, 2001), Cet ke-16, h. 10. Lihat juga dalam karyanya yang berjudul Islam ditinjau dari Berbagai Aspeknya (Jakarta: UI-Press, 1990)

${ }^{31}$ Harold H. Titus, dkk., Persoalan-persoalan Filsafat, terj. M. Rasjidi, (Jakarta: Bulan Bintang, 1984) h. 186-188. 
pengetahuan. Dengan demikian, tiga problema ini akan dibedah dalam paper ini terutama epistemologi pidana budūd dalam bingkai hukum pidana Islam (HPI).

Lebih lanjut, apabila pengertian epistemologi tersebut dikaitkan dengan entitas figh jinayah (hukum pidana Islam), maka epistemologi hukum pidana Islam akan mengacu pada kajian tentang hakikat (realitas), sumber dan metode dan validitas (ukuran) kebenaran. Ketiga ranah tersebut akan menjadi kerangka pikir dan landasan dalam membedah

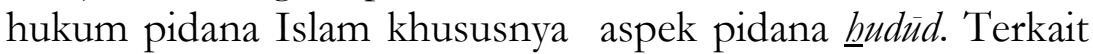
dengan problema-problema dalam epistemologi fiqh jinayah itu sendiri, dalam hal ini Mohammed Arkoun menegaskan bahwa dalam khazanah keilmuan ke-Islaman tradisional, yang dimaksud dengan epistemologi dalam hukum pidana Islam adalah disiplin ilmu ushul al-fiqh atau yang dikenal dengan teori hukum Islam. Ushul al-figh merupakan metodologi terpenting yang ditemukan oleh dunia pemikiran Islam dan tidak dimiliki umat lainnya. ${ }^{32}$

Kedudukan ushūl al-fiqh sebagai epistemologi hukum pidana Islam (jinayah) bersifat mutlak. Sebab disiplin inilah yang mempunyai kaidah-kaidah dasar yang harus diperhatikan dalam merumuskan hukum pidana Islam. Selain itu, ushül alfiqh juga dinilai sebagai metodologi penetapan (itsbät) sebuah hukum. Sebagai sebuah epistemologi, ushül al-fiqh sudah layak dan memadai. Alasannya pada pertimbangan bahwa ushül alfiqh di dalamnya memuat kriteria-kriteria yang dibutuhkan bagi sebuah epistemologi: hakikat (realitas), sumber dan metode serta validitas (ukuran sebuah kebenaran) yang kesemuanya telah teruji dalam pembentukan hukum Islam

${ }^{32}$ Dalam pandangan Arkoun, ilmu (kajian) Ushul al-Figh terutama kaitannya dengan kajian hukum Islam, maka sejatinya Ushul al-Fiqh merepresentasikan kajian epistemologi tersendiri dalam hukum Islam. Perkembangan dan corak, karakteristik hukum Islam (figh) sangat ditentukan oleh Ushul al-Fiqh itu sendiri. Lihat dalam Muhammed Arkoun, "The Concept of Authority in Islamic Thought" dalam Mehdi Mozaffari and Ferdinand (ed.). Islam: State and Society, (London" Curzon-Press, 1988), h. 62. 
dari waktu ke waktu. Dalam beberapa literatur juga disepakati bahwa ushül al-fiqh sangat identik dengan metodologi hukum Islam.

Proses perjalanan sejarah perumusan dan pembaruan metodologi hukum Islam (ushül al-fiqh), paling tidak dijumpai tiga karya besar yang dipandang merepresentasikan zamannya dan karakteristiknya masing-masing. Pertama, adalah karya besar al-Syafi'i yang bernama al-Risālah. Kedua, adalah karya alSyathibi dengan al-Muwāfaqāt-nya, dan ketiga adalah karya Sharur yang berjudul al-Kitäb wa al-Qur'an dan Nabnw Ushül alJadìdah li al-Fiqh al-Islàmi.

Karakteristik yang ada ushül al-fiqh karya al-Syafi'i adalah teologis-deduktif yang terpaku pada literalisme teks. Corak semacam ini kemudian diikuti oleh para teoritisi dari kalangan mutakallimün baik dari Syafi'iyyah, Malikiyyah maupun Hanabilah. Sedangkan dari teoritisi Hanafiyah mempunyai corak yang berbeda dengan menekankan pendekatan induktif-analitis. Kendati demikian, karya-karya ushül al-figh dari kalangan Syafi'iyyah dan Hanafiyyah mempunyai kesamaan yaitu sama-sama menekankan paradigma tekstualisme (literalisme). ${ }^{33}$ Paradigma tekstual ini berjalan selama berabad-abad kurang lebih lima abad, yaitu dari abad ke-2 H sampai abad ke-7 H.

Perjalanan sejarah pembaruan ushül al-fiqh berikutnya adalah pada awal abad ke-8 H/14 M. Ini ditandai dengan munculnya paradigma baru dalam ushül al-fiqh yang diusung oleh al-Syathibi (w.790/1388) melalui karya monumental yang berjudul al-Muwäfaqät fi Ushül al-Syarìah. Melalui karyanya ini al-Syathibi telah menawarkan teori baru yang mengacu pada maksud Allah yang paling utama dalam perumusan hukum. Sebuah revolusi teori yang lebih menekankan pendekatan maqāshidy dari pada pendekatan kebahasaan (lughawi) yang 
selama ini banyak digunakan para teoritisi sebelumnya. ${ }^{34}$ Selepas era al-Syathibi, kajian ushül al-fiqh mengalami stagnasi luar biasa. Ini ditandai dengan kemandegan kajian dan dinamika metode studi Islam. Gagasan al-Syathibi lahir pada masa umat Islam larut dalam keterpakuan teks yang kuat. Sehingga, ide-ide cemerlang yang diretas oleh al-Syathibi pada masanya ku-rang mendapatkan respon dari umat Islam saat itu. ${ }^{35}$ Kendati demikian, apresiasi patut dilayangkan buat alSyathibi yang telah merumuskan teori baru di tengah era keterpakuan teks.

Teori al-Syathibi yang lahir pada abad ke-14 M ini dalam perjalanannya juga terus direvitalisasi oleh para pembaru hukum Islam. Tepatnya lima abad kemudian, di era modern telah bermunculan para pembaru ushül al-figh. Sebut saja nama Muhammad 'Abduh (w. 1905) dengan karyanya yang telah diedit oleh Dr. 'Imarah yang berjudul al-A'mäl alKämilah li al-Imàm Muhammad 'Abduh. Berikutnya adalah Rasyid Ridla' (w. 1935) dengan karyanya yang berjudul Yusr al-Islām wa Ushül al-Tasyrì al''Ām, disusul oleh pembaru berikutnya yaitu 'Abd al-Wahhab Khallaf (w. 1956) dengan karyanya yang berjudul Mashädir al-Tasyrì fi ma Là Nashsha fïhi dan Hasan al-Turabi dari Sudan dengan karyanya Tajdìd Ushül al-Fiqh. Ada juga nama 'Allal al-Fasi (w.1973). Namun demikian, para teoritisi tersebut dalam pandangan Hallaq, belum merumuskan teori baru, melainkan hanya melakukan revitalisasi teori mashlahah yang diretas oleh al-Syathibi. Oleh karena itu, Wael B. Hallaq menyebut bahwa para teoritisi tersebut termasuk dalam kelompok pembaru penganut aliran utilitarianisme. ${ }^{36}$

${ }^{34}$ Louay Safi, Ancangan Metodologi Alternatif (The Fondation of Knowledge; A Comparative Study in Islamic and Western Methods of Inquiry, terj. Imam Khoiri, (Yogyakarta: Tiara Wacana, 2001) h. 143.

${ }^{35}$ Duski Ibrahim, Metode Penetapan Hukum Islam; Membongkar Konsep alIstiqra' al-Ma'nawi al-Syathibi, (Yogyakarta: Ar-Ruzz Media, 2008), h. 186-188.

${ }^{36}$ Wael B. Hallaq, op. cit., h. 318-333. 
Selanjutya, perjalanan sejarah pembaruan hukum Islam telah merambah kepada wilayah kajian teks-teks suci keagamaan. Kajian epistemologis ini terumuskan dalam pertanyaan bagaimanakah teks-teks tersebut dapat diterjemahkan dan diaplikasikan dalam konteks modern dan perubahan sosial? Pertanyaan demikian, menurut para teoritisi hukum Islam kontemporer seperti: Muhammad Sa'id Asymawi (Mesir, 1932-), Fazlur Rahman (Pakistan 1919-1988 M) dengan teori double movement-nya, Mahmoud Muhammed Taha (Sudan, 1910-1985 M) dengan teori nasakh terbalik, Mohammed Arkoun (Aljazair) dengan teori antropologi wabyu, Muhammad Syahrur (Syuriah) dengan nazhariyyah al-budüd, Asghar Ali Engineer (India) dengan teori teologi pembebasan, Mohammad Abid al-Jabiri (Maroko) dengan trilogi nalar (bayani, burhani, irfani) dan Abdullahi Ahmed al-Na'im (Sudan, 1946-) dengan teori dekonstruksi Syariah-nya serta lainlainnya, tidak akan pernah dapat diselesai-kan dengan berpijak pada teori mashlabah klasik di atas. Bahkan, dalam pan-dangan mereka teori mashlabah klasik tidak lagi representatif untuk merumuskan hukum Islam dihadapkan dengan problemproblem modernitas. Bahkan bagi para teoritisi liberal yang diwakili oleh Said al-Asmawi, Fazlur Rahman dan Syahrur, oleh Wael B. Hallaq karena coraknya liberal cenderung tidak mengakui (membuang) teori-teori ushul al-fiqh klasik. ${ }^{37}$ Namun demikian, Amin Abdullah memandang bahwa para pembaru tersebut sama-sama memandang perlu dan mendesak dilakukannya rekonstruksi epsitemologi (baca: metodologi) hukum Islam dan dikembangkan sesuai kebutuhan zaman. ${ }^{38}$

Sejarah telah mencatat bahwa Muhammad Abduh merupakan pembaru yang paling lantang yang menyerukan perlu dilakukannya rancang-bangun metodo-logi hukum

\footnotetext{
${ }^{37}$ Ibid., h. 348-351.
}

${ }^{38} \mathrm{M}$. Amin Abdullah, "Preliminary Remarks on The Philoshophy of Islamic Religious Science" dalam al-Jami'ah: Journal of Islamic Studies No. 61 tahun 1998, h. 6-7. 
Islam. Tentunya dengan tujuan agar hukum Islam dapat beradaptasi dengan dunia modern. Abduh beragumentasi bahwa selama ini umat Islam terlah tenggelam dalam taqlid buta. Karenanya ia menyerukan pendobrakan pintu ijtihad yang dipandang tertutup. Artinya, umat Islam sejatinya mampu mereformasi hukum dengan tetao berlandaskan Alqur'an dan Sunnah yang valid. Perjuangan Abduh diiringi dengan langkah aplikatifnya yang melakukan: rekonsepsi ijma', maksimalisasi peran akal dalam memahami nash, maksimalisasi prinsip mahslabah serta memanfaatkan pendapat pakar hukum di masa lalu dengan metode talfiq. ${ }^{39}$ Pendek kata, gagasan Abduh dalam pembaruaan hukum Islam apabila dilihat dari kacamat sejarah, merupakan embrio sekaligus inspirator bagi pemikir-pemikir berikutnya yang muncul pada abad modern.

Persoalannya kemudian, pada ranah aplikasi, upaya transformasi fiqh jinayah bidang pidana budüd dalam konteks Indonesia semakin rumit ketika melihat realitas bahwa aspek keilmuan (epistemologi) hukum Islam di Indonesia mengalami krisis luar biasa. ${ }^{40} \mathrm{Hal}$ ini dibuktikan dengan tesis Martin Van Bruinessan menyatakan bahwa dalam rentang ratusan tahun keilmuan hukum Islam dunia (termasuk Indonesia), kajian metodologi hukum Islam (ushül al-fiqh) banyak diwarisi dan didominasi kitab-kitab ushül al-fiqh karya Imam al-Syafi'i (w. $204 \mathrm{H}$ ) dan pengikutnya. ${ }^{41}$ Tesis Martin

39 Tentang metode Abdu dapat dilihat dalam Malcolm H. Kerr, Islamic Reform: The Political and Legal Theories of Mubammad Abduh and rashid Rida (Barkeley and Los Angeles: University of California Press, 1966) lihat juga dalam Wael B. Hallaq, op. cit., 218-225. Lihat juga dalam Khoiruddin Nasution, Riba dan Poligami; Sebuah Studi atas Pemikiran Muhammad 'Abduh (Yogyakarta: Pusataka Pelajar-ACAdeMia, 1996), h. 24-30.

40 Terkait problematika dalam upaya-upaya transformasi hukum pidana Islam ke dalam hukum pidana nasional baca dalam karya para pakar Indonesia dalam Muhammad Amin Summa dkk, Pidana Islam di Indonesia; Peluang, Prospek dan Tantangan (Jakarta: Pustaka Firdaus, 2001).

${ }^{41}$ Martin Van Bruinessan, Kitab Kuning, Pesantren dan Tarekat (Bandung: Mizan, 1995), h. 112-124. 
diperkuat pandangan Ahmad Rofiq, bahwa muatan kitabkitab ushül al-fiqh, terutama kitab-kitab ushül al-fiqh Syafi'iyyah, langka dan jarang ditemukan bahasan yang membicarakan metodologi hukum Islam semisal istihbsän, istishläh dan sadd aldzarîah. Kajian-kajiannya lebih banyak metode analogi (qiyās) selain sumber Alqur'an, Sunnah dan Ijma'. Pembicaraan tentang tema ijtihad dalam kitab-kitab tersebut dapat dibenarkan sepanjang dalam frame qiyass. ${ }^{42}$

Padahal dalam kurun waktu sekian abad kemudian, pengikut al-Syafi'i, yakni al-Ghazali (w.1111 M ) mengkritik tajam metode qiyas dengan menga-takan: "man qäla anna al-qiyāsa wa al-ijtihäda lafdžnini faqad khatha" (barang siapa yang mengatakan bahwa qiyas dan ijtihad adalah dua kata yang sama, maka ia telah melakukan kesalahan). ${ }^{43}$ Perjalanan sejarah pembaruan metodologi hukum Islam dilanjutkan oleh al-Syathibi (w.790 H/1388 M) yang mencetuskan paradigma maqashid al-syariah. Gagasan alSyathibi telah memberikan corak baru dalam kajian ilmu ushul al-fiqh. Ia membuat reformasi ulang dengan mengusung teori baru yang berbasis pada maqāshid Syäri' (Allah) sebagai dasar dan pijakan dalam merumuskan hukum Islam. Lewat sentuhan al-Syathibi, ilmu ushül al-fiqh tidak lagi terkungkung pada literalisme teks-teks semata. Dengan demikian, perjuangan al-Syathibi dengan teori maqäshid-nya semakin mengukuhkan fenomena pergeseran-pergeseran ilmu. Ushül fiqh baginya, bukanlah ilmu yang tetap dan anti-perubahan, melainkan terbuka dengan pembaruan.

Selanjutnya, pembaruan metodologi hukum Islam terus berkembang di tangan Muhammad Syahrur seorang teoritisi asa Syiria. Melalui karyanya yang berjudul Naḅw Ushül

${ }^{42}$ Ahmad Rofiq, Kritik Metodologi Hukum Islam Indonesia, dalam Anang Haris Himawan (ed.) dalam "Epistemologi Syara" (Semarang: IAIN Walisongo Press, 1998), h. 100-103.

${ }^{43} \mathrm{Abu}$ Hamid al-Ghazali, al-Mushtasyfa min Tlm al-Ushul, (Beirut: Dar al-Fikr, t.th.,), h. 229. 
Jadìdah li al-Fiqh al-Islämì menawarkan teori baru dalam kajian ushül al-fiqh dengan gagasan historis-ilmiah. Tawaran Syahrur dalam teorinya dapat dipahami sebagai upaya pemanfaatan prestasi ilmiah masa kini, bukan sistem pengetahuan masa lampau untuk merumuskan hukum Islam secara khusus dan pe-ngembangan ilmu-ilmu keislaman lainnya secara umum. ${ }^{44}$ Oleh sebab itu, konsepsi ijtihad Syahrur mensyaratkan secara mutlak pemakaian piranti ilmu-ilmu modern dan prestasi ilmiah kontemporer dalam merumuskan hukum Islam. ${ }^{45}$ Bagi Syahrur, syari'at Allah sejatinya hanyalah syariat yang berupa batas-batas ( $\underline{\text { hudud }}$ ) dan bukan syariat dalam arti konkret ('ayni). Dengan demikian, maka tugas manusia adalah menemukan budūd Allah dalam ayat umm al-kitab. Setelah budüd Allah dapat ditemukan, maka tugas mujtahid adalah merumuskan hukum-hukum yang tidak boleh melam-paui budūd Allah itu sendiri. ${ }^{46}$ Untuk tujuan ini, Syahrur memandang perlu bahwa ijtihad harusa berbasis pada buktibukti material statistik akurat yang mampu menunjukkan kemaslahatan dan kemudahan bagi manusia. Walhasil, ijtihad tidak boleh dilakukan dengan dasar dugaan dan perasaan an sich. 47

Di Indonesia sendiri, corak dan karakteristik hukum Islam yang ada --termasuk entitas al-fiqh al-jinä $\bar{l}^{--}$disinyalir masih banyak diwarnai pemikiran bernuansa Arab dan Timur Tengah yang sejatinya dalam beberapa hal tidak lagi relevan dengan kesadaran hukum masyarakat Indonesia yang telah melembaga dalam hukum adat. Akibatnya, menurut sebagian ahli, ada bagian-bagian tetentu dari hukum Islam yang kurang mendapat sambutan hangat dari masyarakat Indonesia. Dalam

${ }^{44}$ Muhammad Syahrur, Dirāsah Islämiyyah Mu'āsharah (Damaskus: alAhali li al-Thiba'ah wa al-Nasyr wa al-Tauzi', cet. 1, 1994) h. 35-41.

${ }^{45}$ Ibid., h. 55-56.

${ }^{46}$ Muhammad Syahrur, al-Kitäb wa al-Qur'ān (Damaskus: al-Ahali li alThiba'ah wa al-Nasyr wa al-Tauzi', 1992) h. 459.

${ }^{47}$ Wael B. Hallaq, op. cit., h. 370-374. 
bidang fiqh jināyah kita menyaksikan hukum potong tangan bagi pencuri, kesaksian kaum perempuan tidak dapat menjadi bukti dalam perkara-perkara pidana, kaum laki-laki lebih tinggi tingkatannya dari pada perempuan dan lain-lainya. Bentuk-bentuk hukuman pidana tersebut, menurut Munawwir Sjadzali, adalah hukuman bernuansa Arab. ${ }^{48}$

Realitas-realitas empiris di atas pada gilirannya kemudian mendorong perlu dilakukannnya rekonstruksi epistemologi-metodologi untuk mewujudkan fiqh (hukum Islam) bercirikan ke-Indonesiaan. Ide dan gagasan ini banyak diusung oleh pembaru-pembaru Indonesia seperti Hasbi AshShiddieqy dengan "fikih Indonesia", Hazairin dengan "fikih madzhab nasional", Ibrahim Hossein dengan teori "zawäjir", Ali Yafie dan Sahal Mahfudh dengan "fikih sosial" dan Abdurrahman Wahid dengan "pribumisasi Islam", Nurcholis Madjid dengan "sekularisasi Islam" dan lain-lainya. ${ }^{49}$

\section{Relevansinya Bagi Pembangunan Hukum}

\section{Nasional}

Transformasi fiqh jinayah ke dalam hukum pidana nasional saat ini sesuatu yang seharusnya niscaya. ${ }^{50} \mathrm{Hal}$ tersebut bukan saja karena mayoritas masyarakat Indonesia adalah muslim, tetapi juga karena secara historis fiqh jinayah Islam pernah hidup di bumi Indonesia. Namun demikian, hukum pidana Islam (fiqh jinayah) yang ditawarkan harus

${ }^{48}$ Munawwir Sjadzali, Ijtihad Kemanusiaan, (Jakarta: Paramadina, 1997), h. 4-26 Baca juga buku karya Muhammad Wahyuni Nafis dkk (ed.), Kontekstualisasi Ajaran Islam 70 Tahun Prof. Dr. Munawwir Sjadzali, MA, (Jakarta: Paramadina, 1995)

${ }^{49} \mathrm{Ibnu}$ Burdah (ed.) dalam Muhyar Fanani, Membumikan Hukum Langit: Nasionalisasi Hukum Islam dan Islamisasi Hukum Nasional pasca Reformasi, (Yogyakarta: Tiara Wacana, 2008), h. 114.

${ }^{50}$ Pada tahun 2001, pemerintah Indonesia telah membuat rancangan undang-undang Hukum Pidana terdiri dari 647 pasal yang dalam beberapa pasalnya telah memasukkan fiqh jinayah ke dalam kitab tersebut. Namun demikian, hingga saat ini kitab undang-undang tersebut masih sebatas draf yang belum disahkan oleh DPR. Lebih detainya lihat Ahmad Djazuli, Ilmu figh; Penggalian dan Penerapan Hukum Islam, (Jakarta: Kencana, 2010) h. 193-194 
hukum pidana yang dinamis, elastis sejalan dengan karakteristik bangsa Indonesia yang pluralistik, tanpa mengabaikan tujuan-tujuan syariah.

Diakui, upaya ini akan menemui sejumlah problem, semisal problem historisitas, sosial-budaya, institusional dan kendala internal hukum pidana Islam sendiri. Kendalakendala ini harus dicarikan solusinya agar transformasi ini dapat berjalan dengan baik. Mempertimbangkan problemproblem di atas, maka model penerapan hukum pidana Islam yang paling tepat adalah dengan mengkompromikan fiqh jinayab dengan hukum pidana (warisan Belanda) yang berlaku saat sekarang ini. Artinya, penerapannya tidak harus formaltekstual, akan tetapi substansial-kontekstual. Dengan demikian, hukum pidana Indonesia mendatang benar-benar dapat diterima oleh seluruh lapisan masyarakat dan diharapkan mampu membentuk masyarakat Indonesia yang taat hukum serta berakhlak mulia.

Akhirnya, dalam konteks kajian figh jinayah keIndonesiaan, epistemologinya lebih memilih untuk melakukan upaya akomodasi akan adat dan tardisi hukum pidana lokal (local wisdom) yang berkembang. Tentunya setelah dilakukannya objektivikasi baik dari aspek istilah-istilah teknis dan bentuk-bentuk hukumannya. Dari apek peristilahan sedapat mungkin tidak menggunakan istilah atau huruf Arab dan dari aspek bentuk dapat dikompromikan dengan teoriteori pemidanaan modern. Upaya objektivikasi ini bukan bertujuan untuk menghilangkan figh jinayah itu sendiri. Melainkan semata-mata untuk menghindari kesalahpahaman yang tiada perlu. Dengan metode ini diharapkan fiqh jinayah secara substansial tetap bisa menjadi bagian dari masyarakat muslim, meski simbol-formal tidak begitu nampak di permukaan. Inilah yang menurut penulis sesuai dengan kaidah ma la yudraku kullubu la yutraku kullubu.

Di akhir catatan paper ini, dengan rekonstruksi epistemologi figh jinayah Indonesia, maka gagasan transformasi tersebut harus dipetakan wilayah fiqh jinayah yang 
substansial (qath'i) dan mana yang parsial (dzanny). Dalam konteks dan dan bidang budud misalnya, tujuh bidang: zina, qadraf, syurb al-khamr dan yang lainnya delik pidana sudah saatnya dicover dalam hukum pidana nasional. Namun penulis melihat dalam hal bentuk hukuman tidak harus sama dengan tawaran Alqur'an. Sebab hukuman potong tangan, rajam dan sebagainya merupakan wasilah bukan ghayah.

Dalam titik inilah menarik mencermati gagasan Ibrahim Hosen yang menekankan pendekatan ta'aqquli dalam hukum pidana Islam. Pendekatan ini sangat penting dalam mengedepankan aspek zawajir-nya. ${ }^{51}$ Yakni hukuman dilakukan agar pelaku pidana merasa jera, tidak akan mengulangi perbuatan tersebut. Dengan demikian maka bentuk hukuman tidak terikat pada bunyi teks (nash). Atas dasar ini seorang pencuri bisa saja dihukum selain potong tangan. Asalkan hukuman tersebut mampu membuat jera pelaku dan tidak akan mengulanginya lagi dan membuat orang lain takut. Demikian halnya dengan hukuman pelaku tindak pidana budud lainnya. Ibrahim Hosen diapandang orang yang setuju bahwa sanksi hukum bentuk potong tangan dan rajam tidak relevan diterapkan di Indonesia. Menurutnya, potong tangan, dera dan rajam bukanlah tujuan hukum itu sendiri, melainkan sebagai instrumen agar membuat pelaku pidana jera. Karenanya dalam konteks ini, syariat menjadi relatif, bisa dirubah dan dikontekstualisasikan. ${ }^{52}$ Lebih lanjut, menurut Hosen, hukum tidak bergantung pada sebuah benda atau barang yang dihasilkan, tetapi terkait dengan perbuatan manusia (mukallaf). Dan, pemutusan sebuah hukum sangat terkait dengan masalik al-illat.

${ }^{51} \underline{h t t p: / / f a i . u h a m k a . a c . i d ~ d i u n d u h ~ t a n g g a l ~} 20$ Mei 2013.

52 http://fai.uhamka.ac.id diunduh tanggal 20 Mei 2013. Pandangan Hosen tentang zawajir ditentang keras oleh Satria Effendi. Menurut Effendi, dalam hukum potong tangan terdapat fungsi jawabir dan zawajir. Menanggapi reaksi ini Hosen mengatakan bahwa ia merupakan wasilah bukan tujuan atau ghayah. 
Dengan epistemologi demikian, maka transformasi fiqh jinayah menjadi hukum nasional terbuka untuk diterima masyarakat Indonesia. Dalam kasus zina misalnya, KUHP tidak menganggap kasus zina ghairu muhsan (persetubuhan ilegal antara dua orang yang belum menikah atau tidak terikat dalam perkawinan, atas dasar suka sama suka) sebagai suatu tindak pidana. Zina dalam KUHP hanya mencakup persetubuhan ilegal antara dua orang, atau salah-satunya, yang sudah menikah. Tampaknya, KUHP tidak melihat adanya unsur kejahatan pada kasus zina ghairu mubsan, karena tidak ada pihak yang merasa dirugikan. Secara sekilas mungkin benar, akan tetapi jika dikaji lebih jauh, perbuatan tersebut bukan saja akan merugikan keluarga dan masyarakat setempat, bahkan kedua pelaku tersebut. Zina dapat merusak tatanan masyarakat, bertentangan dengan akhlak yang mulia[54], bertentangan dengan agama, bahkan bertentangan dengan budaya nasional yang ketimuran. Delik zina ini pun seharusnya bisa diubah dari delik aduan menjadi delik biasa.

Kasus lain adalah meminum minuman keras, KUHP memandang perbuatan tersebut bukan suatu delik, selama tidak membahayakan orang lain. Sedangkan hukum pidana Islam menganggapnya sebagai jarimah, walaupun pelakunya tidak membahayakan orang lain. Hal ini disebabkan hukum Islam berpijak pada akhlak mulia dan kemaslahatan masyarakat, termasuk individu itu sendiri.

Tentu banyak lagi jarimah yang bisa dijadikan delik dalam hukum pidana positif yang tidak mungkin diuraikan satu-persatu dalam paper ini. Namun demikian jarimah-jarimah tersebut haruslah dipahami secara kontekstual, dinamis dan elastis, sehingga benar-benar layak dijadikan bagian dari hukum pidana nasional. Sebagai contoh adalah jarimah riddah yang konsepnya belum jelas dan penjatuhan sanksinya diwarnai suasana perang pada masa Nabi.

Dilihat dari segi bentuk hukuman fiqh jinayah sering mendapat kritik akibat masih diterapkannya ketentuan rajam (melempar dengan batu sampai terpidana meninggal) dan jilid 
(cambuk). Dalam hukum Islam belakangan ini diusulkan adanya perubahan orientasi jinayat. Dahulu, pemidanaan dalam Islam dimaksudkan sebagai unsur pembalasan dan penebusan dosa. Inilah yang melatarbelakangi lahirnya teori jawabir. Namun, telah muncul teori baru yang menyatakan bahwa tujuan jinayat itu adalah untuk menimbulkan rasa ngeri bagi orang lain agar tidak berani melakukan tindak pidana. Teori yang belakangan ini dikenal dengan teori zawajir. Jadi, bagi penganut teori jawabir, hukuman potong tangan dan qisas itu diterapkan apa adanya sesuai bunyi nash, sedangkan penganut teori zawajir berpendapat bahwa hukuman tersebut bisa saja diganti dengan hukuman lain, semisal hukuman penjara, asalkan efek yang ditimbulkan mampu membuat orang lain jera untuk melakukan tindak pidana.

Dengan demikian, bentuk-bentuk hukuman fisik, seperti rajam dan potong tangan, sedapat mungkin dihindari atau diberikan kriteria yang ekstra ketat dan memenuhi tujuan penjatuhan hukuman tersebut yaitu represif dan preventif. Di samping hal-hal di atas, konstribusi hukum pidana Islam juga bisa diberikan dalam bentuk asas-asas yang disarikan dari hukum pidana Islam. Asas-asas ini kemudian dijadikan sebagai asas hukum materiil yang konstitutif, artinya masuk dalam KUHP, dan dijadikan perspektif dalam pembentukan hukum pidana nasional.

\section{Kesimpulan}

Berdasarkan uraian dan analisis di atas, maka dapat diambil kesimpulan sebagai berikut: Pertama, teori-teori pembaruan dalam hukum pidana Islam yang diusung para teoritisi Islam membuktikan bahwa hukum Islam mempunyai daya murunah (dinamis) dalam merespons dinamika perubahan hukum yang begitu cepat. Kedua, pembaruan teori-teori pemidanaan dalam hukum Islam merupakan jalan yang ideal dalam menemukan "titik temu" antara pemidanaan Islam dengan teori pemidanaan kontemporer. Dengan demikian pada gilirannya, hukum pidana Islam dapat dikembangkan 
dalam konteks pembangunan hukum nasional; Ketiga, Pembangunan hukum Pidana Islam paling ideal dilakukan dengan pendekatan maqashidy istishlaby. Artinya, untuk menyatukan fiqh jinayah dengan hukum pidana nasional. Dengan demikian maka epistemologi fiqh jinayah Indonesia mendukung desimbolisasi dan objektivikasi pidana Islam selama dalam koridor menjaga dan meruwat maqashid alsyariah. Dengan metode penentuan prinsip-prinsip fundamental dan universal inilah, niscaya fiqh jinayah dapat ditransforamsikan ke dalam Hukum Pidana Nasional.

\section{Daftar Pustaka}

A. Qodri A. Azizy, Eklektisisme Hukum Nasional; Kompetisi Antara Hukum Islam dan Hukum Umum, Yogyakarta: Gama Media, 2002

Abdullah, M. Amin, "Preliminary Remarks on The Philoshophy of Islamic Religious Science" dalam alJami'ah: Journal of Islamic Studies No. 61 tahun 1998

Abi Sulaima, 'Abd al-Wahhab Ibrahim, al-Fikru al-Ushuli; Dirasab Tabliliyyah Naqdiyyah, Jeddah: Dar al-Syuruq, 1983

al-Ghazali, Abu Hamid, al-Mushtasyfa min Tlm al-Ushul, Beirut: Dar al-Fikr, t.th.,

Al-Qathhaan, Manna' Mabahist fi Ulum al-Qur'an, t.tp, Mansyurat al-"Ashr al-Hadits, t.th.

Amal, Taufik Adnan, Islam dan Tantangan Modernitas, Studi Atas Pemikiran Hukum Fazlur Rahman, Bandung: Mizan, 1994

An-Na'im, Abdullahi Ahmed, "Mahmud Muhammad Taha and Crisis in Islamic Law Reform: Implications for Interreligious Relations", Journal of Ecumential Studies 25: 11988 
An-Na'im, Abdullahi Ahmed, Islam dan Negara Sekuler; Menegosiasikan Masa Depan Syariah, terj. Sri Murniati Bandung: Mizan, 1997

An-Na'im, Abdullahi Ahmed, Toward an Islamic Reformation: Civil Liberties, Human Rights and International Law New York: Syracuse University Press, 1996

Anwar, Syamsul, "Pengembangan Metode Penelitian Hukum Islam” dalam Ainurrofiq (ed.), Mazhab Jogja”; Menggagas Paradigma Ushul Fiqh Kontemporer, Yogyakarta: Ar-Ruzz Press dan Fakultas Syariah IAIN Sunan Kalijaga, 2002

Assyaukanie, Luthfi, "Tipologi dan wacana Pemikiran Arab Kontemporer" dalam Jurnal Pemikiran Islam Paramadina", vol. 1, No. 1, 1998.

Bruinessan, Martin Van, Kitab Kuning, Pesantren dan Tarekat, Bandung: Mizan, 1995

Burdah, Ibnu (ed.), Membumikan Hukum Langit: Nasionalisasi Hukum Islam dan Islamisasi Hukum Nasional Pasca Reformasi, Yogyakarta: Tiara Wacana, 2008

Djazuli, Ahmad, Ilmu figh; Penggalian dan Penerapan Hukum Islam, Jakarta: Kencana, 2010

Effendi, Satria M, "Ijtihad Sepanjang Sejarah Hukum Islam: Memposisikan KH Ali Yafie" dalam Jamal D. Rahman (ed.) Wacana Baru Figh Sosial; 70 Tahun KH Ali Yafie, Bandung: Mizan, 1997

Effendy, Bahtiar, Islam dan Negara: Transformasi Pemikiran dan Praktik Politik Islam di Indonesia, Jakarta: Paramadina, 1998

Fanani, Muhyar, Metode Studi Islam; Aplikasi Sosiologi Pengetahuan Sebagai Cara Pandang, Yogyakarta: Pustaka Pelajar, 2013

Ghofur, Abdul, Demokratisasi dan Prospek Hukum Islam di Indonesia: Studi atas Pemikiran Gus Dur Yogyakarta: Pustaka Pelajar, 2002

Hallaq, Wael B., A History of Islamic Legal Theories Sejarah Teori Hukum Islam; Pengantar Untuk Ushul al-Fiqh Madz̧bab 
Sunni) terj. E. Kusnadiningrat dan Abdul Haris dari Jakarta: Rajawali Pers, 2000

Hidayat, Komarudin, Memahami Bahasa Agama Jakarta: Paramadina, 1996

Hosen, Ibrahim, Pembaruan Hukum Islam di Indonesia Jakarta: Putra Harapan, 1990

Ibrahim, Duski, Metode Penetapan Hukum Islam; Membongkar Konsep al-Istiqra' al-Ma'nawi al-Syathibi Yogyakarta: ArRuzz Media, 2008

Mubarok, Ahmad Zaki, Pendekatan Strukturalisme Linguistik dalam tafsir Alquran, Yogyakarta: Elsaq Press, 2007

Mujani, Saiful, Muslim Demokrat: Islam, Budaya Demokrasi dan Partisipasi Politik di Indonesia Pasca Orde Baru, Jakarta: Gramedia, 2007

Nurrohman dan Marzuki Wahid, Formaslisasi Syariat Islam dan Fundamentalisme, Kasus Nanggroe Aceh Darussalam dalam Jurnal Istigro' Volume 01, Nomor 1, 2002

Panitia Penyusunan Biografi Prof. KH. Ibrahim Hosen, Prof. KH. Ibrabim Hosen dan pembaharuan Hukum Islam di Indonesia, Jakarta; CV. Tiga Sembilan, 1990

Praja, Juhaya S., Teori Hukum dan Aplikasinya, Bandung: Pustaka Setia, 2011

Rahman, Fazlur, "Islamic Modernism: Its Scope, Method and Alternatives" dalam International Journals of Middle East Studies, Vol. I, tahnun 1970

Rahman, Fazlur, "The Concept of Hadd in Islamic Law" dalam Islamic Studies Journal, Vol. IV, No. 3 September 1965.

Rofiq, Ahmad, Kritike Metodologi Hukum Islam Indonesia, dalam Anang Haris Himawan (ed.) dalam "Epistemologi Syara" Semarang: IAIN Walisongo Press, 1998

Safi, Louay, Ancangan Metodologi Alternatif (The Fondation of Knowledge; A Comparative Study in Islamic and Western Methods of Inquiry, terj. Imam Khoiri Yogyakarta: Tiara Wacana, 2001 
Sjadzali, Munawwir, Ijtihad Kemanusiaan, Jakarta: Paramadina, 1997),

Muhammad Wahyuni Nafis dkk (ed.), Kontekstualisasi Ajaran Islam 70 Tabun Prof. Dr. Munawwir Sjadzali, MA, Jakarta: Paramadina, 1995

Summa, Muhammad Amin dkk, Pidana Islam di Indonesia; Peluang, Prospek dan Tantangan, Jakarta: Pustaka Firdaus, 2001

Sutrisno, Fazlur Rabman; Kajian Kritis terbadap Metode, Epistemologi dan sistem Pwndidikan, Yogyakarta: Pustaka Pelajar, 2006

Syahrur, Muhammad, al-Kitāb wa al-Qur'ān, Damaskus: alAhali li al-Thiba'ah wa al-Nasyr wa al-Tauzi', 1992

Syahrur, Muhammad, al-Kitab wa Alqur'an; Qira'ah Mu'asharah, Damaskus: al-Ahali, 1990

Syahrur, Muhammad, Dirāsah Islämiyyah, Mu'āsharah Damaskus: al-Ahali li al-Thiba'ah wa al-Nasyr wa alTauzi', cet. 1, 1994

Syaukani, Imam, Rekonstruksi Epistemologi Hukum Islam Indonesia, Jakarta: Raja Grafindo Persada, 2006 